\title{
KARAKTERISTIK MORFOLOGI UKURAN TUBUH KERBAU MURRAH DAN KERBAU RAWA DI BPTU SIBORONGBORONG
}

\author{
(Characteristics of Body Size of the Murrah Bufallo and Swamp Bufallo \\ in BPTU Siborongborong)
}

\author{
Gerli $^{1}$, Hamdan ${ }^{2}$ dan Armyn Hakim Daulay ${ }^{2}$
}

1. Mahasiswa Program Studi Peternakan Fakultas Pertanian Universitas Sumatera Utara

2. Staf Pengajar Program Studi Peternakan Fakultas Pertanian Universitas Sumatera Utara

\begin{abstract}
One way to determine the phenotypic diversity of buffaloes is through morphometric observations on each type of buffalo in Indonesia. Morphometric identification can be done by comparing the size and shape of the body. This study aims to obtain information related phenotypic morphometric characteristic of the body Murrah buffalo and swamp buffalo by Principal Component Analysis. The research was conducted in BPTU Siborongborong Kabupaten Tapanuli Utara on Juli up to September 2012. The reseach used 68 swamp buffalo (7 males, 61 females) and 32 Murrah buffaloes (5 males, 27 females) using a survey method. The results statistical showed that the body sizes of Murrah bufallo had higher variances than that Swamp bufallo. Body measurements were showed highly significant differences $(P<0,01)$ in body length, shoulder height, hip height and chest circum, and no significant differences $(P>0,05)$ for chest width, chest depth and hip width. The results principal component analysis showed that the size of the breeds are identifier through shoulder height and the shape is characterized from the chest width. The groups of data between the Murrah bufallo and the Swamp bufallo were significantly different for the shape, while for size has no different. It is concluded that the Murrah bufallo and the Swamp bufallo were significantly different for the shape while has no different for size.
\end{abstract}

Keywords: Murrah Buffalo, Swamp Bufallo, Morphometrics, Principal Component Analysis.

\begin{abstract}
ABSTRAK
Salah satu cara untuk menentukan keragaman fenotipik ternak kerbau adalah dengan pengamatan morfometrik pada setiap jenis kerbau di Indonesia. Identifikasi morfometrik dapat dilakukan dengan cara membandingkan ukuran dan bentuk tubuh. Penelitian ini bertujuan untuk memperoleh informasi fenotipik yang berhubungan dengan karakter morfometrik tubuh kerbau murrah dan kerbau rawa berdasarkan Analisis Komponen Utama. Penelitian dilaksanakan di BPTU Siborongborong Kabupaten Tapanuli Utara pada Juli sampai September 2012. Menggunakan 68 kerbau rawa (7 jantan, 61 betina) dan 32 kerbau murrah (5 jantan, 27 betina) dengan metode survei. Hasil analisis statistika menunjukkan ukuran-ukuran tubuh kerbau murrah lebih beragam dibandingkan kerbau rawa. Ukuran menunjukkan perbedaan sangat nyata $(\mathrm{P}<0,01)$ pada panjang badan, tinggi pundak, tinggi pingggul dan lingkar dada, dan tidak berbeda nyata $(\mathrm{P}>0,05)$ pada lebar dada, dalam dada dan lebar pinggul. Hasil analisis komponenen utama menunjukkan penciri ukuran pada kedua bangsa adalah tinggi pundak dan penciri bentuk adalah lebar dada. Kerumunan data pada kerbau murrah dan kerbau rawa terpisah pada bentuk, sedangkan tidak terpisah pada skor bentuk, sedangkan tidak terpisah pada skor ukuran. Kesimpulan pada penelitian ini adalah kerbau murrah dan kerbau rawa berbeda bentuk sedangkan ukuran sama.
\end{abstract}

Kata Kunci : Kerbau Murrah, Kerbau Rawa, Morfometrik, Analisis Komponen Utama. 


\section{PENDAHULUAN}

Kerbau dapat berkembang baik dalam rentang kondisi agroekosistem yang luas dari daerah dengan kondisi yang basah sampai dengan kondisi yang kering (Hardjosubroto, 2006). Di Indonesia sebagian besar terdiri dari kerbau lumpur (swamp bufallo), namun telah muncul berbagai spesifikasi mengikuti anggroekosistem yang membentuknya (Siregar et al., 1997), sementara ada sekitar 5\% kerbau sungai seperti Murrah di sekitar Medan (Murti, 2002).

Pemanfaatan utama ternak kerbau sampai saat ini selain sumber daging juga merupakan ternak pekerja. Populasi kerbau di Indonesia pada tahun 2005 adalah 2.128.491 ekor, menurun menjadi 2.045.548 ekor pada tahun 2009, dimana sebagian besar kerbau dipelihara oleh peternak kecil dengan tingkat kepemilikan 2-3 ekor. Sementara data pemotongan pada tahun 2005 sekitar 163.848 dan pada tahun 2009 menjadi 166.380 ekor (Ditjennak, 2009).

Kualitas kerbau Indonesia pada umumnya mengalami kemunduran, sebagai akibat penurunan mutu genetik dan faktor lain seperti menejemen pemeliharaan yang kurang tepat. Penurunan produktivitas selain dicerminkan dengan penurunan bobot badan sebagai akibat dari penurunan ukuran-ukuran linear permukaan tubuh kerbau, juga disebabkan faktor genetik karena upaya pemuliaan yang belum terarah.

Pelestarian keragaman ternak diperlukan dalam upaya mempertahankan sifat-sifat khas yang dapat dimanfaatkan di masa mendatang. Salah satu cara penentuan keragaman fenotipik lokal Indonesia adalah dengan pengamatan morfometrik pada bangsa kerbau lokal Indonesia. Identifikasi morfometrik dilakukan dengan cara menentukan penciri ukuran dan bentuk pada masing-masing kerbau lokal berdasarkan Analisis Komponen Utama (AKU). Bentuk sangat dipengaruhi faktor genetik, sedangkan ukuran lebih dipengaruhi faktor lingkungan. Tujuan pemeliharaan kerbau juga turut mempengaruhi keragaman ukuran pada kerbau-kerbau yang ada di Indonesia.

\section{BAHAN DAN METODE PENELITIAN}

\section{Lokasi dan Waktu Penelitian}

Penelitian dilaksanakan di BPTU Babi dan Kerbau Siborongborong Kabupaten Tapanuli Utara, Sumatera Utara pada Juli sampai September 2012. 


\section{Bahan dan Alat}

\section{Bahan}

Bahan yang digunakan dalam penelitian ini adalah 100 ekor kerbau yang terdiri atas 68 kerbau rawa ( 7 jantan, 61 betina) dan 32 kerbau murrah ( 5 jantan, 27 betina) telah mencapai umur sesuai dengan kriteria yang telah akan dibagi berdasarkan tingkatan umur dan jenis kelamin.

\section{Alat}

Peralatan yang digunakan adalah tongkat ukur, pita ukur, buku dan alat tulis serta kamera digital. Komputer yang dilengkapi dengan Software statistik MINITAB ${ }^{\circledR}$ 16.2.1.0. sebagai alat bantu olah data.

\section{Metode}

Penelitian ini menggunakan metode survei dengan menggunakan data primer dan data sekunder. Data primer diperoleh dengan dengan pengamatan dan pengukuran langsung terhadap sampel. Pengambilan sampel dilakukan secara purposive sampling, yaitu sampel ditentukan berdasarkan kriteria mencapai umur dewasa tubuh. Data sekunder yang berhubungan dengan penelitian diperoleh dari Dinas Peternakan Sumatara Utara, Balai Pembibitan Ternak Unggul Babi dan Kerbau Sinur Siborong - Borong. Penggolongan umur ditentukan berdasarkan pemunculan tanduk dan penanggalan gigi seri dan diperkirakan sudah mencapai dewasa tubuh serta dari data recording yang ada.

\section{Parameter Penelitian}

Parameter (variabel) yang diamati dalam penelitian ini adalah lingkar dada, lebar dada, dalam dada, tinggi pundak, panjang badan, tinggi pinggul dan lebar pinggul dengan berat badan sebagai tambahan data deskriptif yang diukur mengunakan timbangan. 


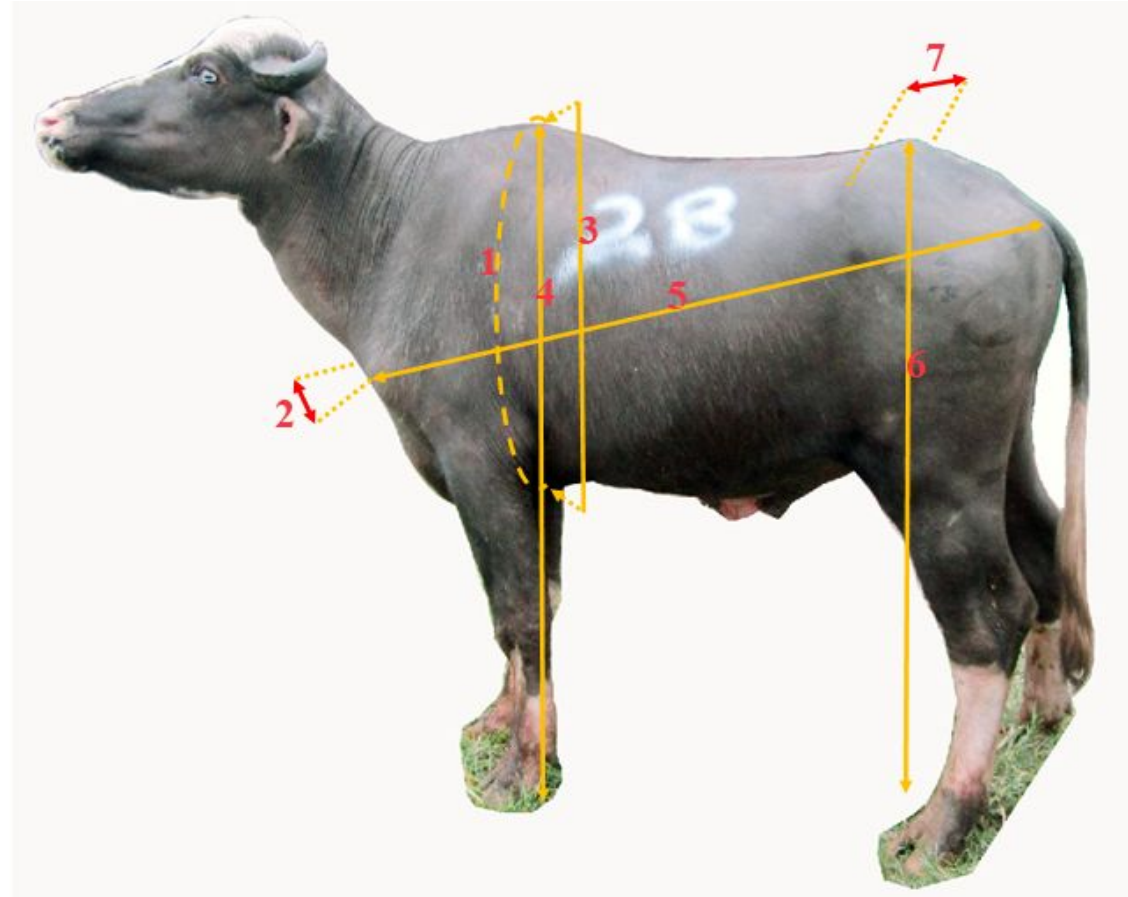

Gambar 1. Metode pengukuran variabel-variabel linier permukaan tubuh kerbau yang diamati

Keterangan: Nomor 1-7 berurutan adalah : 1). Lingkar dada. 2). Lebar dada, 3). Dalam dada. 4). Tinggi pundak. 5). Panjang badan. 6). Tinggi pinggul. 7). Lebar pinggul.

Bagian bagian tubuh kerbau yang diukur (dinyatakan dalam satuan $\mathrm{cm}$ ) dan definisinya diuraikan debagai berikut:

1. Lingkar dada $\left(\mathrm{X}_{1}\right)$ diukur melingkar tepat dibelakang scapula menggunakan pita ukur.

2. Lebar dada $\left(\mathrm{X}_{2}\right)$ adalah jarak antara penjolan sendi bahu (os scapula) kiri dan kanan, diukur dengan pita ukur.

3. Dalam dada $\left(\mathrm{X}_{3}\right)$ merupakan jarak antara titik tertinggi pundak dan tulang dada, diukur dengan menggunakan tongkat ukur.

4. Tinggi pundak $\left(\mathrm{X}_{4}\right)$ jarak tertinggi pundak melalui belakang scapula tegak lurus ke tanah diukur dengan menggunakan tongkat ukur.

5. Panjang badan $\left(\mathrm{X}_{5}\right)$ adalah garis lurus dari tepi tulang processus spinocus sampai dengan benjolan tulang lapis (os ischium), diukur dengan menggunakan tongkat ukur.

6. Tinggi pinggul $\left(\mathrm{X}_{6}\right)$ adalah jarak tertingi pinggul secara tegak lurus ke tanah, diukur dengan menggunakan tongkat ukur.

7. Lebar pinggul $\left(\mathrm{X}_{7}\right)$ diukur dengan tongkat ukur sebagai jarak lebar antara kedua sendi pinggul (Erdiansyah, 2008). 


\section{Analisis Data}

Pengolahan data untuk mendapatkan gambaran dari ukuran tubuh dan bentuk tubuh kedua bangsa kerbau dilakukan dengan menggunakan analisis multivariat yaitu dengan menggunakan Principal Component Analysis atau Analisis Komponen Utama untuk mengetahui hubungan antar variabel dari bangsa kerbau dan digunakan sebagai upaya matematis untuk menyederhanakan variabel menjadi variabel baru, namun variabel baru masih tetap dapat menentukan sebagian besar informasi data asalnya.Karakteristik ukuran tubuh dilakukan dengan menghitung nilai rataan, simpangan baku (S), dan koefisien keragaman (KK) dari setiap sifat yang diamati dengan menggunakan Principal Component Analysis.

$$
\mathrm{S}=\frac{\sum(\mathrm{xi}-\overline{\mathrm{x}})^{2}}{\mathrm{n}-1} \quad \mathrm{KK} \%=\frac{\mathrm{s}}{\overline{\mathrm{x}}}(100 \%)
$$

Keterangan :

$$
\begin{array}{ll}
\bar{x} & =\text { nilai rataan } \\
\mathrm{n} & =\text { jumlah sampel yang diperoleh } \\
\mathrm{Xi} & =\text { ukuran ke-i dari sifat } \mathrm{x} \\
\mathrm{S} & =\text { Simpangan baku } \\
\mathrm{KK} & =\text { koefisien keragaman }
\end{array}
$$

Data ukuran tubuh selanjutnya dianalisis dengan menggunakan Analisis Komponen Utama. Menurut Gaspersz (1992) pengolahan data dengan menggunakan Analisis Komponen Utama dilakukan dengan model matematika sebagai berikut:

$$
Y_{p}=a_{1 p} X_{1}+a_{2 p} X_{2}+a_{3 p} X_{3}+a_{4 p} X_{4}+\ldots .+a_{n p} X_{n}
$$

Keterangan :

$\mathrm{Y}_{\mathrm{p}} \quad=$ komponen utama ke-p

$\mathrm{a}_{1 \mathrm{p}}, \mathrm{a}_{2 \mathrm{p}}, \ldots \mathrm{a}_{\mathrm{np}}=$ vektor ciri/vektor Eigen ke-1,..., $\mathrm{n}$ pada komponen utama ke-p

$\mathrm{X}_{1}, \mathrm{X}_{2}, \ldots, \mathrm{X}_{\mathrm{n}} \quad=$ peubah-peubah yang diamati yaitu:

(tinggi pundak, tinggi pinggul, lebar pinggul, panjang badan, lingkar dada, dalam dada, lebar dada)

Everitt dan Dunn (1998) menyatakan bahwa komponen utama pertama dinyatakan sebagai vektor ukuran, sedangkan komponen utama kedua sebagai vektor bentuk. Keeratan hubungan antara peubah asal dan komponen utama dapat dilihat melalui besarnya koefisien korelasi antara peubah asal dan komponen utama itu. 
Rumus yang digunakan untuk mencari korelasi antara peubah asal dan komponen utama tertentu sebagai berikut:

$$
\mathbf{r}_{\mathbf{x}, \mathbf{y} 1}=\mathbf{r}_{\mathrm{ij}}=\frac{a i j \sqrt{d j}}{s i}(\text { Gaspersz, 1992). }
$$

Keterangan:

$\mathbf{r}_{\mathbf{x}, \mathbf{y} \mathbf{1}}=\mathbf{r}_{\mathbf{i j}} \quad=$ koefisien korelasi

$\mathrm{a}_{\mathrm{ij}} \quad=$ vektor penciri/vektor Eigen ke-i pada komponen utama ke-j

$\sqrt{\lambda j} \quad=$ akar dari nilai penciri/ nilai eigen pada komponen utama ke-j

$\mathrm{S}_{\mathrm{i}} \quad=$ simpangan baku dari variabel $\mathrm{X}_{\mathrm{i}}$

Selanjutnya skor komponen utama yang diperoleh dari persamaan ukuran tubuh disajikan dalam bentuk diagram kerumunan. Diagram kerumunan dibuat berdasarkan skor komponen utama pertama (skor ukuran) sebagai sumbu $\mathrm{X}$ dan skor komponen utama kedua (skor bentuk) sebagai sumbu Y; yang diperoleh berdasarkan persamaan ukuran dan bentuk. Perbedaan kerumunan data antara kedua bangsa kerbau yang diamati diperbandingkan pada diagram kerumunan.

\section{HASIL DAN PEMBAHASAN}

\section{Deskriptif Statistik Ukuran Linier Permukaan Tubuh Kerbau Murrah dan Kerbau Rawa}

Ukuran-ukuran linear peubah ukuran tubuh kerbau murrah dan kerbau rawa yang diukur meliputi tinggi pundak, tinggi pinggul, lebar pinggul, panjang badan, lingkar dada, dalam dada, lebar dada dan penimbangan bobot badan yang dikelompokkan menurut umur dan jenis kelamin berbeda, tabel berikut menyajikan nilai rataan, simpangan baku dan koefisien keragaman pada masing - masing peubah yang diamati disajikan pada Tabel 1 dan Tabel 2.

Rataan berat badan kerbau murrah jantan pada kelompok umur $2-3,5$ tahun $258 \mathrm{~kg}$ dan pada kerbau rawa jantan $246 \mathrm{~kg}$. Rawa jantan muda hasil pengamatan didapat tinggi pundak 115,5 cm, tinggi pinggul 117,5 cm, panjang badan 105,5 cm dan lingkar dada 182,5 $\mathrm{cm}$, lebih rendah dibandingkan penelitian (Praharani dan Triwulanningsih, 2007) yaitu tinggi pundak 122,80 cm, tinggi pinggul 125,40 cm, panjang badan 123,20 cm dan lingkar dada 190,22 cm. Kerbau murrah jantan muda memiliki rataan ukuran tubuh tidak jauh berbeda dengan kerbau rawa jantan muda kecuali pada lingkar dada. Dari hasil uji-t terdapat perbedaan yang sangat nyata $(\mathrm{P}<0,01)$ pada jantan muda yaitu pada variabel panjang badan. Keragaman ukuran tubuh pada kerbau murrah jantan muda sekitar 1,11 - 8,09\% dan ukuran tubuh pada kerbau rawa jantan muda sekitar 1,77-4,47\%. 
Ukuran tubuh (tinggi pundak, tinggi pinggul, lebar pinggul, panjang badan, lingkar dada, dalam dada, lebar dada) dipengaruhi oleh umur ternak jenis kelamin. Secara umum, rataan ukuran tubuh kerbau muda lebih rendah dari ternak dewasa. Pada kerbau jantan dewasa ukuran tubuh kerbau rawa tidak berbeda jauh dengan kerbau murrah. Keragaman ukuran tubuh pada kerbau murrah jantan dewasa sekitar $0,76-10,60 \%$ dan ukuran tubuh pada kerbau rawa jantan dewasa sekitar $1,28-6,45 \%$.

Tabel 1. Rataan, simpangan baku, dan koefisien keragaman ukuran-ukuran tubuh kerbau murrah dan kerbau rawa jantan

\begin{tabular}{|c|c|c|c|c|c|c|c|}
\hline \multirow{3}{*}{ Variabel } & \multirow{3}{*}{ Bangsa } & \multicolumn{6}{|c|}{ Kelompok umur } \\
\hline & & \multicolumn{3}{|c|}{$2-3,5$} & \multicolumn{3}{|c|}{$3,5-7$} \\
\hline & & $\mathrm{n}$ & $\bar{x} \pm \mathrm{S}$ & KK \% & $\mathrm{n}$ & $\bar{x} \pm \mathrm{S}$ & KK \% \\
\hline \multirow{2}{*}{ Bobot badan } & Murrah & 2 & $258,00 \pm 14,71^{\text {tn }}$ & 5,70 & 3 & $474,20 \pm 73,06^{\mathrm{tn}}$ & 15,39 \\
\hline & Rawa & 4 & $305,17 \pm 16,44^{\text {tn }}$ & 5,39 & 3 & $462,17 \pm 43,67^{\text {tn }}$ & 9,45 \\
\hline \multirow{2}{*}{ Lingkar dada } & Murrah & 2 & $162,50 \pm 6,36^{\mathrm{tn}}$ & 3,92 & 3 & $195,00 \pm 11,36^{\mathrm{tn}}$ & 5,82 \\
\hline & Rawa & 4 & $182,50 \pm 3,69^{\mathrm{tn}}$ & 2,02 & 3 & $203,00 \pm 6,56^{\mathrm{tn}}$ & 3,23 \\
\hline \multirow{2}{*}{ Lebar dada } & Murrah & 2 & $37,00 \pm 1,41^{\text {tn }}$ & 3,82 & 3 & $49,00 \pm 5,19^{\mathrm{tn}}$ & 10,60 \\
\hline & Rawa & 4 & $39,50 \pm 1,29^{\text {tn }}$ & 3,63 & 3 & $50,33 \pm 2,08^{\text {tn }}$ & 4,13 \\
\hline \multirow{2}{*}{ Dalam dada } & Murrah & 2 & $63,50 \pm 0,70^{\text {tn }}$ & 1,11 & 3 & $83,00 \pm 6,56^{\text {tn }}$ & 7,90 \\
\hline & Rawa & 4 & $64,25 \pm 2,87^{\text {tn }}$ & 4,47 & 3 & $82,00 \pm 5,29^{\text {tn }}$ & 6,45 \\
\hline \multirow{2}{*}{ Tinggi pundak } & Murrah & 2 & $115,50 \pm 4,95^{\mathrm{tn}}$ & 4,28 & 3 & $138,67 \pm 4,04^{\text {tn }}$ & 2,91 \\
\hline & Rawa & 4 & $115,50 \pm 2,08^{\mathrm{tn}}$ & 1,80 & 3 & $135,00 \pm 1,73^{\text {tn }}$ & 1,28 \\
\hline \multirow{2}{*}{ Panjang badan } & Murrah & 2 & $122,00 \pm 1,41^{* *}$ & 1,16 & 3 & $148,33 \pm 7,64^{\mathrm{tn}}$ & 5,15 \\
\hline & Rawa & 4 & $105,50 \pm 1,70^{* *}$ & 1,61 & 3 & $141,67 \pm 4,16^{\text {tn }}$ & 2,94 \\
\hline \multirow{2}{*}{ Tinggi pinggul } & Murrah & 2 & $111,50 \pm 5,65^{\text {tn }}$ & 8,09 & 3 & $131,00 \pm 1^{\text {th }}$ & 0,76 \\
\hline & Rawa & 4 & $117,50 \pm 2,08^{\text {tn }}$ & 1,77 & 3 & $132,33 \pm 3,78^{\mathrm{tn}}$ & 2,86 \\
\hline \multirow{2}{*}{ Lebar pinggul } & Murrah & 2 & $44,00 \pm 2,82^{\text {tn }}$ & 6,43 & 3 & $57,33 \pm 5.5^{\mathrm{tn}}$ & 9,61 \\
\hline & Rawa & 4 & $44,00 \pm 1,41^{\text {tn }}$ & 3,21 & 3 & $54,67 \pm 3,51^{\text {tn }}$ & 6,42 \\
\hline
\end{tabular}

Keterangan: Notasi $\bar{x}$ adalah rataan, $\mathrm{n}$ adalah jumlah sampel, $\mathrm{S}$ adalah simpangan baku dan KK adalah koefisien keragaman..

Tanda * menunjukkan perbedaan nyata $(\mathrm{P}<0,05)$ antar bangsa dalam variabel sedangkan ** menunjukkan perbedaan sangat nyata $(\mathrm{P}<0,01)$ antar bangsa dalam variabel. Tanda (tn) menunjukkan perbedaan tidak nyata $(\mathrm{P}>0,05)$ antar bangsa dalam variabel.

Rataan tinggi pundak dan panjang badan dari kerbau murrah jantan dewasa pengamatan adalah 138,67 $\mathrm{cm}$ dan $148.3 \mathrm{~cm}$, lebih rendah dibandingkan penelitian (Mason, 1974) yaitu 142 dan $151 \mathrm{~cm}$, dan menurut Sitorus (2008) yaitu $132 \mathrm{~cm}$ dan $132,8 \mathrm{~cm}$. Ukuran lingkar dada kerbau murrah jantan $(195 \mathrm{~cm})$ yang diamati juga lebih kecil dari yang didapat Fahimuddin (1975) sebesar $220 \mathrm{~cm}$ dan lebih besar dari laporan Sitorus (2008) yaitu $185 \mathrm{~cm}$.

Kerbau rawa jantan dewasa hasil pengamatan didapat tinggi pundak $135,5 \mathrm{~cm}$, tinggi pinggul 132,3 cm, panjang badan 141,6 cm dan lingkar dada $203 \mathrm{~cm}$, lebih besar dibandingkan tinggi pundak 127,35 cm, tinggi pinggul $126,82 \mathrm{~cm}$, panjang badan $131 \mathrm{~cm}$ dan lingkara dada 196,5 cm (Praharani dan Triwulanningsih, 2007) sedangkan dari hasil 
penelitian Sitorus (2008) tinggi pundak 126,38 cm, tinggi pinggul 125,56 cm, panjang badan $129,5 \mathrm{~cm}$ dan lingkar dada $182,16 \mathrm{~cm}$.

Tabel 2. Rataan, simpangan baku, dan koefisien keragaman ukuran-ukuran tubuh kerbau murrah dan kerbau rawa betina

\begin{tabular}{|c|c|c|c|c|c|c|c|}
\hline \multirow{3}{*}{ Variabel } & \multirow{3}{*}{ Bangsa } & \multicolumn{6}{|c|}{ Kelompok umur } \\
\hline & & \multicolumn{3}{|c|}{$2-3,5$} & \multicolumn{3}{|c|}{$3,5-7$} \\
\hline & & $\mathrm{N}$ & $\bar{x} \pm \mathrm{S}$ & KK \% & $\mathrm{n}$ & $\bar{x} \pm \mathrm{S}$ & KK \% \\
\hline \multirow{2}{*}{ Bobot badan } & Murrah & 6 & $241,67 \pm 32,85^{\text {tn }}$ & 13,59 & 21 & $402,98 \pm 52,17^{\mathrm{tn}}$ & 12,94 \\
\hline & Rawa & 4 & $223,65 \pm 16,28^{\mathrm{tn}}$ & 7,28 & 57 & $398,00 \pm 38,46^{\mathrm{tn}}$ & 9,66 \\
\hline \multirow{2}{*}{ Lingkar dada } & Murrah & 6 & $155,33 \pm 7,17^{\mathrm{tn}}$ & 4,62 & 21 & $182,71 \pm 12,77^{\mathrm{tn}}$ & 6,99 \\
\hline & Rawa & 4 & $152,00 \pm 4,69^{\mathrm{tn}}$ & 3,09 & 57 & $188,74 \pm 7,76^{\mathrm{tn}}$ & 4,11 \\
\hline \multirow{2}{*}{ Lebar dada } & Murrah & 6 & $35,00 \pm 1,67^{\text {tn }}$ & 4,78 & 21 & $40,33 \pm 2,56^{\mathrm{tn}}$ & 6.34 \\
\hline & Rawa & 4 & $36,75 \pm 0.96$ & 2,61 & 57 & $39,98 \pm 3^{\text {th }}$ & 7,51 \\
\hline \multirow{2}{*}{ Dalam dada } & Murrah & 6 & $65,33 \pm 4,80^{\mathrm{tn}}$ & 7,35 & 21 & $75,43 \pm 7,26^{\mathrm{tn}}$ & 9,62 \\
\hline & Rawa & 4 & $63,50 \pm 1,9^{\mathrm{tn}}$ & 3,01 & 57 & $75,00 \pm 2,9^{\mathrm{tn}}$ & 3,89 \\
\hline \multirow{2}{*}{ Tinggi pundak } & Murrah & 6 & $122,00 \pm 5,02^{* * *}$ & 4,11 & 21 & $133,00 \pm 4,60^{*}$ & 3,46 \\
\hline & Rawa & 4 & $112,75 \pm 0,5^{\text {** }}$ & 0,44 & 57 & $125,14 \pm 2,44^{*}$ & 1,95 \\
\hline \multirow{2}{*}{ Panjang badan } & Murrah & 6 & $119,17 \pm 7,73^{\text {tn }}$ & 6,49 & 21 & $137,28 \pm 5,57^{* *}$ & 4,06 \\
\hline & Rawa & 4 & $118,25 \pm 1,5^{\mathrm{tn}}$ & 1,27 & 57 & $127,98 \pm 2,41^{* *}$ & 1,89 \\
\hline \multirow{2}{*}{ Tinggi pinggul } & Murrah & 6 & $115,83 \pm 8,23^{\text {tn }}$ & 7,11 & 21 & $130,28 \pm 3,94^{* *}$ & 3,02 \\
\hline & Rawa & 4 & $113,25 \pm 1,5^{\mathrm{tn}}$ & 1,32 & 57 & $124,49 \pm 2,46^{* *}$ & 1,98 \\
\hline \multirow{2}{*}{ Lebar pinggul } & Murrah & 6 & $41,50 \pm 4,13^{\text {tn }}$ & 9,96 & 21 & $53,80 \pm 4.8^{\text {tn }}$ & 9,10 \\
\hline & Rawa & 4 & $41,75 \pm 1,26^{\mathrm{tn}}$ & 3,01 & 57 & $47,35 \pm 3,23^{\text {tn }}$ & 6,82 \\
\hline
\end{tabular}

Keterangan: Notasi $\bar{x}$ adalah rataan, $\mathrm{n}$ adalah jumlah sampel, $\mathrm{S}$ adalah simpangan baku dan KK adalah koefisien keragaman.

Tanda * menunjukkan perbedaan nyata $(\mathrm{P}<0,05)$ antar bangsa dalam variabel sedangkan ** menunjukkan perbedaan sangat nyata $(\mathrm{P}<0,01)$ antar bangsa dalam variabel. Tanda (tn) menunjukkan perbedaan tidak nyata $(\mathrm{P}>0,05)$ antar bangsa dalam variabel.

Kerbau rawa betina muda hasil pengamatan didapat tinggi pundak $112,75 \mathrm{~cm}$, tinggi pinggul 113,25 cm, panjang badan 118,25 cm dan lingkar dada $152 \mathrm{~cm}$, lebih rendah dibandingkan (Praharani dan Triwulanningsih, 2007) yaitu tinggi pundak 117,29 cm, tinggi pinggul 117,88 cm, panjang badan $118,91 \mathrm{~cm}$, lingkar dada 179,44 cm. Hasil uji-t menunjikkan bahwa terdapat perbedaan yang sangat nyata $(\mathrm{P}<0,01)$ pada betina muda yaitu pada variabel tingggi pundak. Kerbau murrah betina muda memiliki rataan ukuran tubuh lebih besar dibanding kerbau rawa betina muda. Keragaman ukuran tubuh pada kerbau murrah betina muda sekitar 4,11 - 9,96\% dan ukuran tubuh pada kerbau rawa betina muda sekitar $0.44-3.09 \%$.

Kerbau murrah betina dewasa hasil pengamatan didapat tinggi pundak $133 \mathrm{~cm}$, tinggi pinggul 130,28 cm, panjang badan 137,28 cm dan lingkar dada 182,71 cm, tidak jauh berbeda dibandingkan laporan Sitorus (2008) yaitu didapati tinggi pundak 133,13 cm, tinggi pinggul 132,5 cm, panjang badan 131,87 cm, kecuali pada lingkar dada 202,59 cm. 
Kerbau Rawa betina dewasa hasil pengamatan didapat tinggi pundak 125,14 cm, tinggi pinggul 124,49 $\mathrm{cm}$, panjang badan $127,98 \mathrm{~cm}$ dan lingkar dada 188,74 $\mathrm{cm}$, lebih besar dibandingkan pada penelitian (Praharani dan Triwulanningsih, 2007) tinggi pundak 122,91 $\mathrm{cm}$, tinggi pinggul $122,72 \mathrm{~cm}$, panjang badan126,96cm, lingkar dada $186,14 \mathrm{~cm}$ sedangkan dari hasil penelitian Sitorus (2008) menunjukkan tinggi pundak 122,26 cm, tinggi pinggul $121,38 \mathrm{~cm}$, panjang badan 119,14 $\mathrm{cm}$ dan lingkar dada 176,6 cm. Keragaman ukuran tubuh pada kerbau murrah betina dewasa sekitar 3,02-9,66\% dan ukuran tubuh pada kerbau rawa betina dewasa sekitar 1,89-7,51\%. Dari hasil uji-t terdapat perbedaan yang nyata $(\mathrm{P}<0,05)$ pada betina induk yaitu pada variabel tinggi pundak sedangkan perbedaan yang sangat nyata $(\mathrm{P}<0,01)$ ditunjukkan pada variabel panjang badan dan tinggi pinggul.

\section{Persamaan Ukuran dan Bentuk Tubuh Kerbau Murrah dan Kerbau Rawa}

Perasaan ukuran, persamaan bentuk, keragaman total, dan nilai eigen pada kerbau murrah dan kerbau rawa disajikan pada Tabel 3 dan Tabel 4.

Tabel 3. Persamaan skor ukuran dan bentuk tubuh dengan keragaman total dan nilai eigen pada kerbau murrah

\begin{tabular}{|c|c|c|}
\hline Persamaan & $\begin{array}{l}\text { Keragaman } \\
\text { total }(\%)\end{array}$ & $\begin{array}{l}\text { Nilai } \\
\text { eigen }\end{array}$ \\
\hline $\begin{aligned} \text { Ukuran }= & 0,377 \mathrm{X}_{1}+0,364 \mathrm{X}_{2}+0,368 \mathrm{X}_{3}+0,401 \mathrm{X}_{4}+0,375 \mathrm{X}_{5} \\
& +0,386 \mathrm{X}_{6}+0,373 \mathrm{X}_{7}\end{aligned}$ & 78,9 & 5,526 \\
\hline $\begin{aligned} \text { Bentuk }= & 0,258 \mathrm{X}_{1}+0,515 \mathrm{X}_{2}-0,378 \mathrm{X}_{3}-0,341 \mathrm{X}_{4}+0,102 \mathrm{X}_{5} \\
& -0,498 \mathrm{X}_{6}+0,388 \mathrm{X}_{7}\end{aligned}$ & 6,7 & 0,468 \\
\hline
\end{tabular}

Keterangan: $\mathrm{X}_{1}=$ Lingkar dada; $\mathrm{X}_{2}=$ Lebar dada; $\mathrm{X}_{3}=$ Dalam dada; $\mathrm{X}_{4}=$ Tinggi pundak; $\mathrm{X}_{5}=$ Panjang badan; $\mathrm{X}_{6}=$ Tinggi Pinggul; $\mathrm{X}_{7}=$ Lebar Pinggul

Persamaan skor ukuran tubuh kerbau murrah memiliki keragaman total sebesar 78,9 yang merupakan proporsi keragaman terbesar diantara komponen - komponen utama yang diperoleh. Nilai eigen yang diperoleh pada persamaan skor ukuran adalah 5,526. Vektor eigen tertingi pada persamaan ukuran ditemukan pada tinggi pundak $\left(\mathrm{X}_{4}\right)$ sebesar 0,401 . Korelasi antara skor ukuran dan tinggi pundak ditemukan sebesar $+0,123$. Tanda positif menunjukkan peningkatan ukuran lingkar dada akan meningkatkan skor ukuran atau sebaliknya. Persamaan bentuk memiliki keragaman total sebesar 6,7 yang merupakan proporsi keragaman terbesar setelah keragaman total pada persamaan ukuran. Nilai eigen pada persamaan skor bentuk ditemukan sebesar 0,468. Vektor eigen tertinggi pada persamaan bentuk ditemukan pada lebar dada $\left(\mathrm{X}_{2}\right)$ sebesar 0,515 yang merupakan penciri bentuk pada kerbau murrah. Korelasi antara skor bentuk dan lebar dada ditemukan sebesar +0,079. 
Tabel 4. Persamaan skor ukuran dan bentuk tubuh dengan keragaman total dan nilai eigen pada kerbau rawa

\begin{tabular}{|c|c|c|}
\hline Persamaan & $\begin{array}{l}\text { Keragaman } \\
\text { total }(\%)\end{array}$ & $\begin{array}{l}\text { Nilai } \\
\text { eigen }\end{array}$ \\
\hline $\begin{aligned} \text { Ukuran }= & 0,380 \mathrm{X}_{1}+0,347 \mathrm{X}_{2}+0,370 \mathrm{X}_{3}+0,410 \mathrm{X}_{4}+0,369 \mathrm{X}_{5}+ \\
& 0,391 \mathrm{X}_{6}+0,376 \mathrm{X}_{7}\end{aligned}$ & 73,5 & 5,114 \\
\hline $\begin{aligned} \text { Bentuk }= & -0,217 \mathrm{X}_{1}-0,573 \mathrm{X}_{2}+0,169 \mathrm{X}_{3}+0,305 \mathrm{X}_{4}+0,422 \mathrm{X}_{5}+ \\
& 0,304 \mathrm{X}_{6}-0,481 \mathrm{X}_{7}\end{aligned}$ & 13,5 & 0,944 \\
\hline
\end{tabular}

Tabel 4 menyajikan persamaan skor ukuran tubuh kerbau rawa yang memiliki keragaman total sebesar 73,5 merupakan proporsi keragaman terbesar diantara komponen komponen utama yang diperoleh. Nilai eigen yang diperoleh pada persamaan skor ukuran adalah 5,114. Vektor eigen tertinggi pada persamaan ukuran ditemukan pada tinggi pundak $\left(\mathrm{X}_{4}\right)$ sebesar 0,410 merupakan penciri ukuran kerbau rawa. Korelasi antara skor ukuran dan tinggi pundak ditemukan sebesar $+0,190$. Persamaan bentuk memiliki keragaman total sebesar 13,5 yang merupakan proporsi keragaman terbesar setelah keragaman total pada persamaan ukuran. Nilai eigen pada persamaan skor bentuk ditemukan sebesar 0,944 . Vektor eigen yang tinggi pada persamaan bentuk ditemukan pada lebar dada $\left(\mathrm{X}_{2}\right)$ sebesar 0,573 merupakan penciri bentuk pada kerbau rawa. Korelasi antara skor bentuk dan lebar dada ditemukan sebesar $-0,153$.

\section{Rekapitulasi Penciri Ukuran dan Bentuk Tubuh pada Kerbau Murrah dan Kerbau Rawa serta Pembentukan Diagram Kerumunan}

Rekapitulasi penciri ukuran dan bentuk pada kerbau murrah dan kerbau rawa yang diamati berdasarkan persamaan ukuran dan bentuk disajikan pada Tabel 5. Gambar 2 menyajikan diagram kerumunan data kerbau murrah dan kerbau rawa berdasarkan perolehan skor ukuran dan skor bentuk.

Tabel 5. Rekapitulasi penciri ukuran dan bentuk tubuh pada kerbau murrah dan kerbau rawa

\begin{tabular}{lll}
\hline Bangsa & Penciri ukuran & Penciri bentuk \\
\hline Murrah & Tinggi pundak $\left(\mathrm{X}_{4}\right)$ & Lebar dada $\left(\mathrm{X}_{2}\right)$ \\
Rawa & Tinggi pundak $\left(\mathrm{X}_{4}\right)$ & Lebar dada $\left(\mathrm{X}_{2}\right)$ \\
\hline
\end{tabular}


Berdasarkan Tabel 5, Tinggi pundak merupakan penciri ukuran pada semua bangsa kerbau yang diamati. Hal ini divisualisasikan dalam bentuk diagram kerumunan pada Gambar 2.

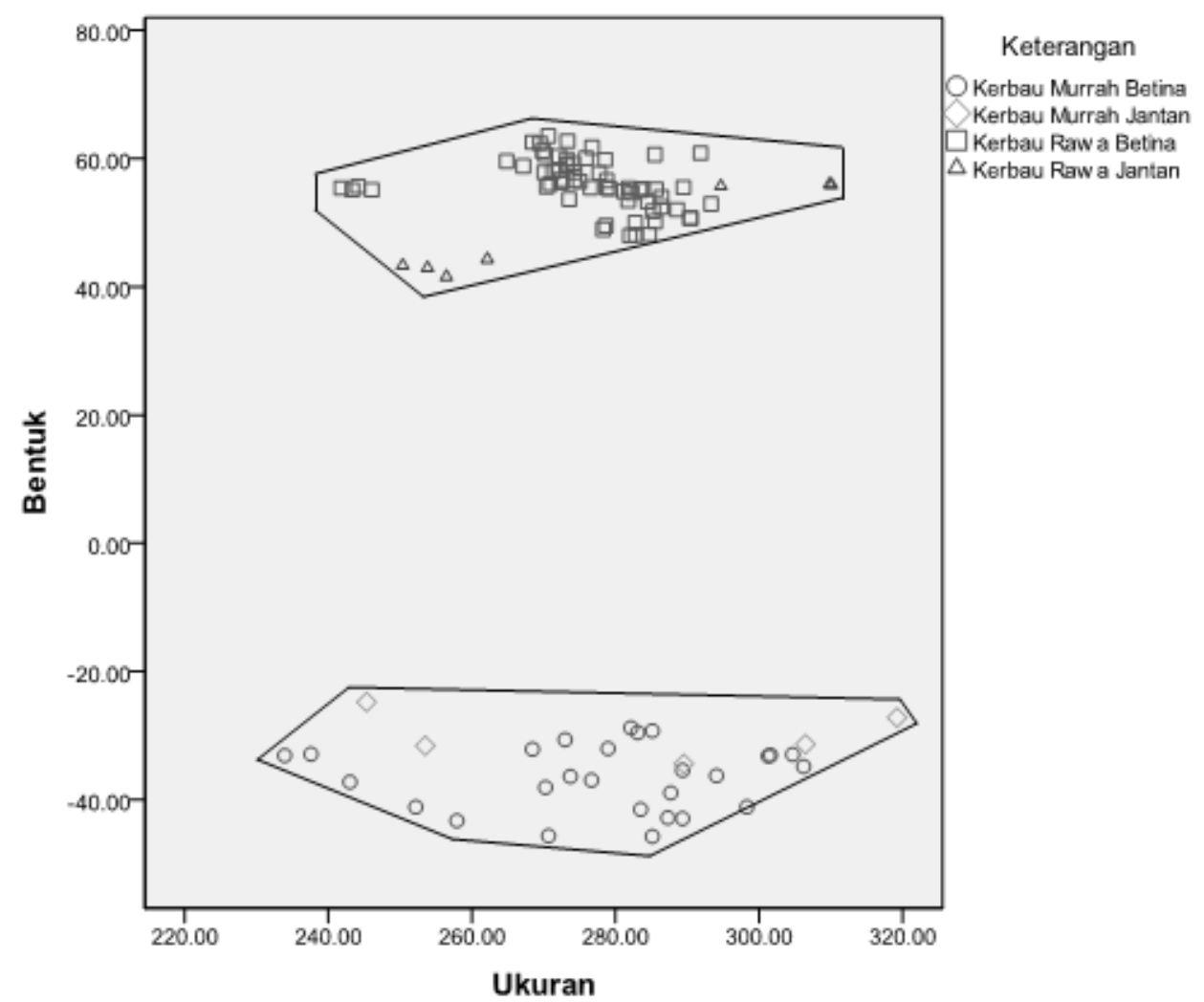

Gambar 2. Diagram kerumunan data skor ukuran dan bentuk tubuh kerbau murrah dan kerbau rawa

Berdasarkan skor ukuran (sumbu-X), kerumunan data kerbau murrah dengan jumlah sampel 32 ekor (5 jantan, 27 betina) berkisar antara 236 - 320; sedangkan dengan jumlah sampel 68 ekor ( 7 jantan, 61 betina) kerbau rawa menyebar pada rentang $244-310$. Tampak bahwa kedua bangsa kerbau menempati rentang yang sama, hanya saja pada kerbau rawa kerumunan data lebih terpusat. Hal ini menggambarkan bahwa secara ukuran kerbau murrah dan kerbau rawa adalah sama.

Bentuk (fenotipik) dipengaruhi faktor genetik dan lingkungan (Hardjosubroto, 1998). Berdasarkan Tabel 5, penciri bentuk ditemukan pada kerbau murrah dan kerbau rawa adalah lebar dada. Berdasarkan Gambar 2, bentuk kedua kelompok kerbau yang diamati tampak berbeda dilihat dari kerumunan data yang ada. Hal ini dapat dijelaskan dengan tidak adanya komponen yang saling berhimpit antara kerbau murrah dan kerrbau rawa. Berdasarkan skor bentuk (sumbu-Y), kerumunan data kerbau murrah terlihat berada pada posisi bawah yaitu pada $-47,5$ - -22,5; sedangkan kerbau rawa tampak pada posisi diatasnya yaitu pada 42,5 65,1 . 


\section{KESIMPULAN}

Analisis deskriptif menunjukkan ukuran-ukuran tubuh kerbau murrah lebih beragam dibandingkan kerbau rawa. Ukuran-ukuran linier tubuh kerbau murrah berbeda dengan kerbau rawa pada variabel panjang badan pada kerbau jantan umur 2 - 3,5 tahun; variabel tinggi pundak pada kerbau betina umur 2 - 3,5 tahun; variabel tinggi pundak, panjang badan dan tinggi pinggul pada kerbau betina umur 3,5 - 7 tahun.

Analisis Komponen Utama menyatakan bahwa tinggi pundak merupakan penciri ukuran dan lebar dada sebagai penciri bentuk pada kerbau murrah dan kerbau rawa. Secara morfologi kerbau murrah dan kerbau rawa sangat berbeda. Hal ini ditunjukkan oleh kerumunan data pada kerbau murrah dan kerbau rawa saling terpisah, walaupun kedua bangsa terlihat sama jika ditinjau dari morfometriknya.

\section{DAFTAR PUSTAKA}

Ditjennak, 2009. Peta potensi wilayah sumber bibit sapi potong lokal dan rencana pengembangannya. www.ditjennak.go.id [7 Januari 2012].

Erdiansyah, E., dan Anneke Anggraeni. 2008. Keagaman Fenotipe dan Pendugaan Jarak Genetic antara Subpopulai Kerbau Rawa Lokal di Kabupaten Dompu, Nusatenggara Barat. Prosiding Seminar dan Lokakarya Nasional Usaha Ternak Kebau Tanah Toraja. 2008. Puslitbang Peternakan, Bogor.

Everitt, B. S \& G. Dunn. 1998. Applied Multivariate Data Analysis. Jhon Wiley and Sons Inc., Illionois.

Fahimuddin, M. 1975. Domestic water buffallo. Oxford and IBH publishing co, New Delhi.

Gazpersz, V. 1992. Teknik Analisi dalam Penelitian Percobaan. Tarsito, Bandung.

Hardjosubroto, W., 1998. Aplikasi Pemuliabiakan di Lapangan. Gramedia widiasarana Indonesia. Jakarta.

Hardjosubroto, W. 2006. Kerbau: mutiara yang terlupakan. UGM press. Yogyakarta.

Mason. I.L. 1974. The Husbandry and Health of The Domestic Buffalo. Food and Agriculture Organization of The United Nation, Rome.

Murti, T. W., 2002. Ilmu Ternak Kerbau. Kanisius. Yogyakarta.

Praharani, Lisa., dan E. Triwulanningsih. 2007. Karakterisasi Bibit Kerbau Pada Agroekosistem Dataran Tinggi. Prosiding Seminar dan Lokakarya Nasional Usaha Ternak Kebau Jambi. Puslitbang Peternakan, Bogor.

Siregar A. R., P. Situmorang, M. Zulbardi, L. P. Batubara, A Wilson, E. Basuno, S.E. Sinulingga dan C.H. Sirait. 1997. Peningkatan produktivitas kerbau dwiguna. Prosiding Seminar nasional dan veteriner. Bogor.

Sitorus, A. J. dan Anneke Anggraeni, 2008. Kkarakterisasi Morfologi dan Estimasi Jarak Genetik Kerbau Rawa, Sungai (Murrah) dan Silangannya di Sumatera Utara. Prosiding Seminar dan Lokakarya Nasional Usaha Ternak Kebau Tanah Toraja. Puslitbang Peternakan, Bogor. 